\title{
THE SPECIFICITY OF IMMUNE HUMAN SERUM ANTIHYALURONIDASE ${ }^{1}$
}

\author{
By ROBERT T. THOMPSON AND FRANCES E. MOSES \\ WITH THE TECH NICAL ASSISTANCE OF BARBARA MOULTON \\ (From the Departments of Internal Medicine and Biochemistry of the College of Medicine, \\ University of Cincinnati, and the Cincinnati General Hospital, Cincinnati)
}

(Received for publication June 15, 1948)

In the light of present knowledge there appear to be two kinds of hyaluronidase inhibition by blood serum. One inhibitor of hyaluronidase has been demonstrated in the serum or plasma of various normal, nonimmunized animals and man (1-6). Haas has reported that this inhibitor is not specific for any particular hyaluronidase, and that it is not an antibody but is an enzyme (3). However, recently Hadidian and Pirie have favored the impression that this inhibitor is analogous to an antitoxin or an antibody (5), and Dorfman, Ott, and Whitney have presented evidence (6) which contests some details of the report of Haas (3). The findings of Dorfman, Ott, and Whitney lend no support to the thesis that this inhibitor is an enzyme, and leave open the question as to whether or not this inhibitor in normal serum specifically antagonizes particular hyaluronidases (6). The other inhibitor of hyaluronidase has been demonstrated in the serum of rabbits which had been immunized with a purified hyaluronidase preparation (7-11). This inhibitor in immune serum specifically antagonizes the particular hyaluronidase which was used as the antigen; it is developed by an immune response to an antigenic stimulus and may be called an antihyaluronidase.

The inhibitor of hyaluronidase in normal, nonimmune serum is thermolabile $(3,5,6)$, whereas the antihyaluronidase of immune serum is thermostable (12).

A previous study demonstrated rises in titer of serum antihyaluronidase antagonistic to pneumococcus hyaluronidase in human patients following pneumococcus bacteremia (12-14), and some inhibition of pneumococcus hyaluronidase by the serum of every one of 50 normal human beings tested $(12,13)$. Only relatively low dilutions of normal sera inhibited the pneumococcus hyalu-

\footnotetext{
1 Supported by a gift in the memory of the late Ben L. Heidingsfeld, and by a grant from the Smith, Kline, and French Laboratories, Philadelphia, $\mathbf{P a}$.
}

ronidase, whereas relatively high dilutions of patients' sera at the peak of immune response inhibited the pneumococcus hyaluronidase (12). The present study demonstrates that this immune response of human antihyaluronidase serum is specifically antagonistic to the hyaluronidase of the particular species of organism from which the immunizing material was derived $(15) .^{2}$

\section{METHODS}

Serial sera of patients who suffered bacteremia due to various kinds of bacteria were titrated against similar strengths of various hyaluronidases. Serial dilutions of each serum to be tested were incubated with a constant amount of one hyaluronidase, and these incubates were tested for residual hyaluronidase activity by Byers' modification (16) of McClean's mucoprotein clot-prevention (M.C.P.) test (11). The highest dilution of the serum which inactivated the constant amount of the hyaluronidase was taken as the antihyaluronidase titer of that serum, referable to the particular hyaluronidase used in the test.

The hyaluronidases used in these tests were unrefined filtrates of 72-hour cultures of Pneumococci Type 1, Type 2, and Type 7; Hemolytic Staphylococcus aureus; beta Hemolytic Streptococcus, and Clostridium perfringens ( $\mathrm{Cl}$. Welchii) ${ }^{3}$ and purified bovine testicular hyaluronidase. 4 The hyaluronidases of the gram positive cocci were prepared by culture in beef heart infusion broth (Difco) which contained $0.75 \%$ potassium hyaluronate and no glucose. Before inoculation this medium was sterilized in the autoclave at ten pounds pressure for 15 minutes. The $\mathrm{Cl}$. Welchii hyaluronidase and the potassium hyaluronate were prepared by the method of Byers, Tytell and Logan (17).

2 This was reported briefly in Federation Proc., 1948, 7, 282.

$3 \mathrm{We}$ are indebted to Dr. A. A. Tytell who prepared and supplied the $\mathrm{Cl}$. Welchii hyaluronidase used in these tests.

4 The purified bovine testicular hyaluronidase was supplied by the courtesy of Dr. R. L. Mayer of Ciba Pharmaceutical Products, Inc. This hyaluronidase was purified by ammonium sulfate fractionation with subsequent dialysis and lyophilization according to the method of L. Hahn, Biochem. Z., 1943, 315, 83, and contained 105 Viscosity Reducing Units per mgm. 
The constant amount of each hyaluronidase used throughout these tests was $0.25 \mathrm{cc}$. of the unrefined hyaluronidase which had been diluted so that either a $1: 8$ or a 1:16 dilution 5 prevented the mucoprotein clot, regardless of the original potency of the hyaluronidase preparation used. The constant amount of the bacterial hyaluronidases was essentially equivalent to the constant amount of the purified bovine testicular hyaluronidase, which contained $0.0013 \mathrm{mgm}$. of the purified hyaluronidase. This dilution of each hyaluronidase was freshly prepared each day that tests were done. All dilutions of hyaluronidase and of serum to be tested were made in $1 \%$ proteose peptone in physiologic saline.

Serum antihyaluronidase was determined in exactly the same way as described in the previous study (12), but the description is repeated here for convenience. All of the sera in one patient's series of sera were tested at one time with one hyaluronidase preparation. Twofold serial dilution, beginning with $1: 2$, was made for each serum tested. Twelve dilutions, each in the volume of $0.5 \mathrm{cc}$. in tubes $100 \mathrm{~mm} . \times 13 \mathrm{~mm}$., were made for each serum. The constant amount of hyaluronidase in the volume of $0.25 \mathrm{cc}$. was added to each serum dilution, and to a control tube containing $0.5 \mathrm{cc}$. of proteose peptone saline with no serum. The final dilution of serum in the first tube was $1: 3$, and the final volume in each tube was $0.75 \mathrm{cc}$. These tubes were mixed by shaking the tube rack, then incubated at room temperature $\left(25^{\circ}\right.$ C. $)$ for 20 minutes.

Residual hyaluronidase activity which remained after incubation of the serum dilution and hyaluronidase mixtures was determined as follows:

(1) $1.0 \mathrm{cc}$. of substrate was added to each tube. This substrate contained equal volumes of three components: dialysed tryptic digest of umbilical cord which contained approximately $0.20 \%$ hyaluronic acid (17), normal horse serum (Lederle) which exhibited neither hyaluronidase nor antihyaluronidase activity, and distilled water.

(2) The tubes were mixed by shaking the tube rack, then incubated in a water bath at $37^{\circ} \mathrm{C}$. for 30 minutes, and then cooled in an ice water bath for five minutes.

(3) 1.0 cc. of $5 \%$ glacial acetic acid was added to each tube, and each tube was shaken individually and read for formation of the mucoprotein clot. The highest dilution of a given serum which exhibited either heavy or thready clot was taken as the antihyaluronidase titer of that serum. Results were expressed in terms of dilution of serum prior to addition of the substrate. Activity of the constant amount of hyaluronidase was demonstrated in the control tube by prevention of the clot.

This mucoprotein clot-prevention test permitted a twofold chance variation of antihyaluronidase titer, but a fourfold chance variation did not occur (12).

\section{RESULTS}

The antihyaluronidase responses obtained in three patients with preumonia and bacteremia are

5 These dilutions represent essentially equivalent hyaluronidase activity within the àccuracy of the test.
TABLE I

Antihyaluronidase titers of serial sera as determined by titration of the sera against the various hyaluronidases; patients with pneumococcic pneumonia and bacteremia Type 25 Pn. pneumonia

\begin{tabular}{|c|c|c|c|c|}
\hline \multirow{2}{*}{$\begin{array}{l}\text { Hyaluronidases } \\
\text { tested }\end{array}$} & \multicolumn{3}{|c|}{ Dates of sera } & \multirow{2}{*}{$\begin{array}{l}\text { Multiple } \\
\text { change }\end{array}$} \\
\hline & $11 / 25 / 46$ & $12 / 2 / 46$ & $12 / 16 / 46$ & \\
\hline $\begin{array}{l}\text { Pn. } 1 \\
\text { Pn. } 2 \\
\text { Pn. } 7 \\
\text { Staph. } \\
\text { Strep. } \\
\text { Welch. }\end{array}$ & $\begin{array}{r}48 \\
48 \\
48 \\
6 \\
3 \\
\angle 3\end{array}$ & $\begin{array}{r}192 \\
192 \\
96 \\
3 \\
\angle 3 \\
\end{array}$ & $\begin{array}{r}768 \\
384 \\
384 \\
6 \\
\angle 3 \\
\angle 3\end{array}$ & $\begin{array}{lr}X & 16 \\
\times & 8 \\
\times & 8 \\
\times & 1 \\
\times & 1 \\
\times & 1\end{array}$ \\
\hline
\end{tabular}

Type 3 Pn. pneumonia

\begin{tabular}{|c|c|c|c|c|c|}
\hline \multirow{2}{*}{$\begin{array}{l}\text { Hyaluronidases } \\
\text { tested }\end{array}$} & \multicolumn{4}{|c|}{ Dates of sera } & \multirow{2}{*}{$\begin{array}{l}\text { Multiple } \\
\text { change }\end{array}$} \\
\hline & $3 / 22 / 47$ & $3 / 28 / 47$ & $4 / 4 / 47$ & $4 / 11 / 47$ & \\
\hline $\begin{array}{l}\text { Pn. 1 } \\
\text { Pn. } 2 \\
\text { Pn. } 7 \\
\text { Staph. } \\
\text { Strep. } \\
\text { Welch. }\end{array}$ & $\begin{array}{r}96 \\
192 \\
96 \\
\angle 3 \\
3 \\
\angle 3\end{array}$ & $\begin{array}{r}384 \\
384 \\
192 \\
\angle 3 \\
3 \\
3\end{array}$ & $\begin{array}{r}1,536 \\
768 \\
768 \\
\angle 3 \\
\angle 3 \\
\angle 3\end{array}$ & $\begin{array}{r}1,536 \\
768 \\
768 \\
- \\
- \\
-\end{array}$ & $\begin{array}{lr}X & 16 \\
X & 4 \\
X & 8 \\
X & 1 \\
x & 1 \\
x & ?\end{array}$ \\
\hline
\end{tabular}

Type 12 Pn. pneumonia

\begin{tabular}{|c|c|c|c|c|c|}
\hline \multirow{2}{*}{$\begin{array}{c}\text { Hyaluronidases } \\
\text { tested }\end{array}$} & \multicolumn{4}{|c|}{ Dates of sera } & \multirow{2}{*}{$\begin{array}{c}\text { Multiple } \\
\text { change }\end{array}$} \\
\hline & $4 / 8 / 47$ & $4 / 15 / 47$ & $4 / 25 / 47$ & $5 / 8 / 47$ & \\
\hline $\begin{array}{l}\text { Pn. } 1 \\
\text { Pn. } 2 \\
\text { Pn. } 7 \\
\text { Staph. } \\
\text { Welch. }\end{array}$ & $\begin{array}{r}96 \\
96 \\
48 \\
3 \\
\end{array}$ & $\begin{array}{r}384 \\
192 \\
96 \\
\angle 3 \\
\end{array}$ & $\begin{array}{r}1,536 \\
192 \\
192 \\
\angle 3 \\
\angle 3\end{array}$ & $\begin{array}{r}1,536 \\
768 \\
384 \\
\angle 3 \\
\angle 3\end{array}$ & $\begin{array}{lr}X & 16 \\
\times & 8 \\
\times & 8 \\
\times & 1 \\
\times & 1\end{array}$ \\
\hline
\end{tabular}

illustrated in Table I. The antihyaluronidase titer is expressed as the reciprocal of the highest dilution of patients' serum which inactivated the test strength of the hyaluronidase used in the titration. The sera of all of these patients exhibited eightfold or greater rises of antihyaluronidase titer as tested with the three pneumococcus hyaluronidases except that the patient with Type 3 pneumonia exhibited only a fourfold rise of titer against Type 2 Pneumococcus hyaluronidase. However, these sera exhibited no rise of titer as tested with other hyaluronidases. Sera of the first two patients exhibited no rise of titer with the staphylococcus, streptococcus, and $\mathrm{Cl}$. Welchii hyaluronidases, and sera of the third patient exhibited no rise of titer as tested with staphylococcus hyaluronidase. The third patient's last two sera exhibited no antagonism of $\mathrm{Cl}$. Welchii hyaluronidase. 
TABLE II

Antihyaluronidase titers of serial sera as determined by titration of the sera against the various hyaluronidases; patients with pneumococcic empyema and bacteremia Type 1 Pn. empyema

\begin{tabular}{|c|c|c|c|c|c|c|c|}
\hline \multirow{2}{*}{$\begin{array}{c}\text { Hyalu- } \\
\text { ronidases } \\
\text { tested }\end{array}$} & \multicolumn{6}{|c|}{ Dates of sera } & \multirow{2}{*}{$\begin{array}{l}\text { Mul- } \\
\text { tiple } \\
\text { change }\end{array}$} \\
\hline & $12 / 19 / 44$ & $12 / 31 / 44$ & $1 / 3 / 45$ & $1 / 18 / 45$ & $1 / 31 / 45$ & $2 / 21 / 45$ & \\
\hline $\begin{array}{l}\text { Pn. } 1 \\
\text { Pn. } 2 \\
\text { Pn. } 7 \\
\text { Welch. }\end{array}$ & $\begin{array}{r}12 \\
3 \\
\angle 3 \\
\angle 3\end{array}$ & $\begin{array}{l}768 \\
768 \\
192 \\
-\end{array}$ & - & - & $\begin{array}{c}384 \\
384 \\
192 \\
-\end{array}$ & $\begin{array}{r}192 \\
192 \\
96 \\
-\end{array}$ & $\begin{array}{r}\times 64 \\
\times 256 \\
\times \quad 64 \\
\times \quad 1\end{array}$ \\
\hline . & \multicolumn{2}{|c|}{$12 / 8 / 44$} & \multicolumn{2}{|c|}{$1 / 4 / 45$} & \multicolumn{2}{|c|}{$1 / 18 / 45$} & \\
\hline \multirow[t]{2}{*}{$\begin{array}{l}\text { Pn. } 1 \\
\text { Pn. } 2 \\
\text { Pn. } 7 \\
\text { Welch. }\end{array}$} & \multicolumn{2}{|c|}{$\begin{array}{r}6 \\
12 \\
\angle 3 \\
\angle 3\end{array}$} & \multicolumn{2}{|c|}{$\begin{array}{l}48 \\
24 \\
\angle 3\end{array}$} & \multicolumn{2}{|c|}{$\begin{array}{l}48 \\
48 \\
24 \\
\angle 3\end{array}$} & $\begin{array}{r}\times 8 \\
\times 4 \\
\times 8 \\
\times 1\end{array}$ \\
\hline & $4 / 10 / 47$ & $4 / 18 / 47$ & $4 / 25 / 47$ & $5 / 6 / 47$ & $5 / 16 / 47$ & $6 / 10 / 47$ & \\
\hline $\begin{array}{l}\text { Pn. } 1 \\
\text { Pn. } 2 \\
\text { Pn. } 7 \\
\text { Staph. } \\
\text { Strep. } \\
\text { Welch. }\end{array}$ & $\begin{array}{l}48 \\
24 \\
24 \\
12 \\
- \\
-\end{array}$ & $\begin{array}{r}96 \\
96 \\
48 \\
3 \\
- \\
\end{array}$ & $\begin{array}{r}384 \\
192 \\
192 \\
24 \\
- \\
-\end{array}$ & $\begin{array}{r}768 \\
768 \\
384 \\
6 \\
\angle 3 \\
\angle 3\end{array}$ & $\begin{array}{r}768 \\
768 \\
384 \\
6 \\
\angle 3 \\
\angle 3\end{array}$ & $\begin{array}{r}768 \\
384 \\
192 \\
12 \\
\angle 3 \\
\angle 3\end{array}$ & $\begin{array}{r}\times 16 \\
\times 32 \\
\times 16 \\
\times \quad 2 \\
\times 1 \\
\times 1\end{array}$ \\
\hline
\end{tabular}

The antihyaluronidase responses obtained in three patients with empyema and bacteremia are illustrated in Table II. Sera of the first patient exhibited rises of antihyaluronidase titer which were 64-fold or greater as tested with the three pneumococcus hyaluronidases, but no antagonism

TABLE III

Antihyaluronidase titers of serial sera as determined by titration of the sera against the various hyaluronidases; pmeumococcic endocarditis patient and staphylococcus bacteremia patient

Type $12 \mathrm{Pn}$. aortic endocarditis with Type $12 \mathrm{Pn}$. bacteremia

\begin{tabular}{|c|c|c|c|c|c|}
\hline \multirow{2}{*}{$\begin{array}{c}\text { Hyalu- } \\
\text { ronidases } \\
\text { tested }\end{array}$} & \multicolumn{4}{|c|}{ Dates of sera } & \multirow{2}{*}{$\begin{array}{c}\text { Mul- } \\
\text { tiple } \\
\text { change }\end{array}$} \\
\hline & $10 / 20 / 47$ & $10 / 29 / 47$ & $11 / 12 / 47$ & $11 / 26 / 47$ & \\
\hline $\begin{array}{l}\text { Pn. } 2 \\
\text { Staph. } \\
\text { Strep. } \\
\text { Welch. }\end{array}$ & $\begin{array}{r}3 \\
24 \\
\angle 3 \\
\angle 3\end{array}$ & $\begin{array}{l}24 \\
24 \\
\angle 3 \\
\angle 3\end{array}$ & $\frac{192}{\angle 3}$ & $\begin{array}{l}48 \\
24 \\
\angle 3 \\
\angle 3\end{array}$ & $\begin{array}{l}\times 64 \\
\times 1 \\
\times 1 \\
\times 1\end{array}$ \\
\hline
\end{tabular}

Hemolytic staphylococcus aureus bacteremia with gastric ulcer

\begin{tabular}{|c|c|c|c|c|c|c|c|}
\hline \multirow{2}{*}{$\begin{array}{c}\text { Hyalu- } \\
\text { ronidases } \\
\text { tested }\end{array}$} & \multicolumn{6}{|c|}{ Dates of sera } & \multirow{2}{*}{$\begin{array}{c}\text { Mul- } \\
\text { tiple } \\
\text { change }\end{array}$} \\
\hline & $10 / 21 / 47$ & $10 / 29 / 47$ & $11 / 5 / 47$ & $11 / 10 / 47$ & $11 / 21 / 47$ & $\mid 12 / 13 / 47$ & \\
\hline $\begin{array}{l}\text { Pn. 2 } \\
\text { Staph. } \\
\text { Strep. } \\
\text { Welch. }\end{array}$ & $\begin{array}{r}3 \\
\frac{3}{\angle 3}\end{array}$ & $\begin{array}{r}6 \\
6 \\
6 \\
\angle 3\end{array}$ & $\frac{6}{=}$ & $\frac{12}{\angle 3}$ & $\begin{array}{l}64 \\
=\end{array}$ & $\frac{7}{6}$ & $\begin{array}{l}\times 2 \\
\times 8 \\
\times 1 \\
\times 1\end{array}$ \\
\hline
\end{tabular}

of $\mathrm{Cl}$. Welchii hyaluronidase. Sera of the second patient exhibited fourfold to eightfold rises of titer as tested with the three pneumococcus hyaluronidases, but no antagonism of $\mathrm{Cl}$. Welchii hyaluronidase. Sera of the third patient exhibited 16fold to 32-fold rises of titer as tested with the three pneumococcus hyaluronidases, with some fluctuation but no definite rise in titer as tested with staphylococcus hyaluronidase. This third patient's last three sera exhibited no antagonism of the streptococcus or $\mathrm{Cl}$. Welchii hyaluronidase.

The antihyaluronidase responses obtained in two other patients are shown in Table III. The first of these patients had Type 12 pneumococcic aortic endocarditis with bacteremia and the second patient had Hemolytic Staphylococcus aureus bacteremia complicating gastric ulcer. Sera of the endocarditis patient exhibited 64-fold rise of antihyaluronidase titer as tested with the Type 2 Pneumococcus hyaluronidase, but no rise of titer as tested with the staphylococcus, streptococcus and $\mathrm{Cl}$. Welchii hyaluronidases. Sera of the patient with staphylococcus bacteremia exhibited eightfold rise of antihyaluronidase titer as tested with the staphylococcus hyaluronidase, elaborated by the organism cultured from this patient's blood, but no significant rise of titer as tested with the pneumococcus and $\mathrm{Cl}$. Welchii hyaluronidases. Too much time elapsed between the two sera which were tested with streptococcus hyaluronidase so that no conclusion can be drawn, but the results suggest that there was no rise in titer of antihyaluronidase antagonistic to the streptococcus hyaluronidase.

The antihyaluronidase responses obtained in two patients with repeatedly positive blood culture due to gram negative bacilli are illustrated in Table IV. The first patient had typhoid fever ${ }^{6}$ which began about October 7, 1947, and the second patient had B. coli bacteremia of undetermined origin with onset of illness about October 2, 1947. Sera of both of these patients exhibited no rise of antihyaluronidase titer as tested with Type 2 Pneumococcus, staphylococcus, streptococcus and $\mathrm{Cl}$. Welchii hyaluronidases. The second patient's sera exhibited an unusually high titer of antihyaluronidase as tested with $\mathrm{Cl}$. Welchii hyaluronidase, for which no explanation is apparent.

6 Typhosus from two different blood cultures of this patient failed to elaborate hyaluronidase in the hyaluronate broth medium. 
TABLE IV

Antihyaluronidase titers of serial sera as determined by titration of the sera against the various hyaluronidases; patients with repeated bacteremia due to gram negative bacilli

Typhoid fever with B. typhosus bacteremia*

\begin{tabular}{c|c|c|c|c|c}
\hline \hline \multirow{2}{*}{$\begin{array}{c}\text { Hyaluronidases } \\
\text { tested }\end{array}$} & \multicolumn{4}{|c|}{ Dates of sera } & Multiple \\
change & & \multicolumn{4}{|c|}{} \\
\cline { 2 - 6 } & $10 / 21 / 47$ & $10 / 30 / 47$ & $11 / 11 / 47$ & $12 / 1 / 47$ & \\
\hline $\begin{array}{l}\text { Pn. 2 } \\
\text { Staph. }\end{array}$ & 6 & - & 6 & 6 & $\times 1$ \\
Strep. & - & - & $\angle 3$ & $\angle 3$ & $\times 1$ \\
Welch. & - & 12 & $\angle 3$ & $\angle 3$ & $\times 1$ \\
& & 12 & 12 & $\times 1$ \\
\hline
\end{tabular}

B. Coli communis bacteremia of undetermined origin $\dagger$

\begin{tabular}{c|c|c|c|c|c}
\hline & \multicolumn{4}{|c|}{ Dates of sera } & \\
$\begin{array}{c}\text { Hyaluronidases } \\
\text { tested }\end{array}$ & \multicolumn{4}{|c|}{$\begin{array}{c}\text { Multiple } \\
\text { change }\end{array}$} \\
\cline { 2 - 6 } & $10 / 16 / 47$ & $10 / 20 / 47$ & $10 / 28 / 47$ & $11 / 20 / 47$ & \\
\hline Pn. 2 & 6 & 3 & 3 & 3 & $\times \frac{1}{2}$ \\
Staph. & $\angle 3$ & - & $\angle 3$ & $\angle 3$ & $\times 1$ \\
Strep. & $\frac{13}{36}$ & $\angle 3$ & $\angle 3$ & - & $\times 1$ \\
Welch. & 96 & 96 & 48 & - & $\times \frac{1}{2}$ \\
\hline
\end{tabular}

* This patient had blood cultures positive for $B$. typhosus on $10 / 14 / 47,10 / 16 / 47,10 / 17 / 47,10 / 30 / 47,11 / 3 / 47$, $11 / 13 / 47,11 / 14 / 47$, and $11 / 18 / 47$.

t This patient had blood cultures positive for $B$. coli communis twice on $10 / 14 / 47$, and once each on $12 / 13 / 47$, $12 / 26 / 47,12 / 30 / 47$, and $2 / 5 / 48$. The diagnosis was possible endocarditis, but the patient died on February 7 , 1948 , and autopsy was not obtained.

The antihyaluronidase responses obtained in three patients with pneumococcus bacteremia are illustrated in Table V. Sera of the first two patients exhibited eightfold to 16-fold rises of antihyaluronidase titer and sera of the third patient exhibited fourfold to eightfold rises of antihyaluronidase as tested with the three pneumococcus hyaluronidases, but no rise in titer as tested with the purified bovine testicular hyaluronidase.

\section{DISCUSSION}

The specificity of immune human serum antihyaluronidase reported here is in agreement with the specificity of immune rabbit serum antihyaluronidase reported by Duran-Reynals (7); Hobby, Dawson, Meyer and Chaffee (8); McClean and Hale (9); and McClean $(10,11)$. The lack of specificity for pneumococcus type exhibited by the antihyaluronidase response in patients with pneumococcus bacteremia has been reported previously (12-14).

These findings agree in principle with those of Friou and Wenner (18) on the specific inhibition of hemolytic streptococcus hyaluronidase by the serum of patients with hemolytic streptococcus infection, but do not support their impression that the streptococcus hyaluronidase is the only hyaluronidase which may be specifically inhibited by human serum.

TABLE V

Antihyaluronidase titers of serial sera as determined by titration of the sera against the hyaluronidases of pneumococcus and bovine testis; patients with pneumococcus bacteremia Type 14 Pn. pneumonia

\begin{tabular}{|c|c|c|c|c|c|}
\hline \multirow{2}{*}{$\begin{array}{l}\text { Hyaluronidases } \\
\text { tested }\end{array}$} & \multicolumn{4}{|c|}{ Dates of sera } & \multirow{2}{*}{$\begin{array}{l}\text { Multiple } \\
\text { change }\end{array}$} \\
\hline & $4 / 7 / 47$ & $4 / 15 / 47$ & $4 / 22 / 47$ & $5 / 6 / 47$ & \\
\hline $\begin{array}{l}\text { Pn. 1 } \\
\text { Pn. } 2 \\
\text { Pn. } 7 \\
\text { Testis }\end{array}$ & $\begin{array}{r}96 \\
48 \\
48 \\
3\end{array}$ & $\begin{array}{r}384 \\
384 \\
384 \\
\angle 3\end{array}$ & $\begin{array}{l}768 \\
384 \\
384 \\
-\end{array}$ & $\begin{array}{l}768 \\
768 \\
768 \\
\angle 3\end{array}$ & $\begin{array}{l}\times \quad 8 \\
\times 16 \\
\times 16 \\
\times 11\end{array}$ \\
\hline
\end{tabular}

Type 11 Pn. empyema with mesothelioma of pleura

\begin{tabular}{|c|c|c|c|}
\hline \multirow{2}{*}{$\begin{array}{c}\text { Hyaluronidases } \\
\text { tested }\end{array}$} & \multicolumn{2}{|c|}{ Dates of sera } & \multirow{2}{*}{$\begin{array}{c}\text { Multiple } \\
\text { change }\end{array}$} \\
\hline & $4 / 19 / 47$ & $4 / 25 / 47$ & \\
\hline $\begin{array}{l}\text { Pn. 1 } \\
\text { Pn. } 2 \\
\text { Pn. } 7 \\
\text { Testis }\end{array}$ & $\begin{array}{l}96 \\
96 \\
48 \\
\angle 3\end{array}$ & $\begin{array}{r}1,536 \\
768 \\
1,536 \\
\angle 3\end{array}$ & $\begin{array}{r}\times 16 \\
\times \quad 8 \\
\times 32 \\
\times \quad 1\end{array}$ \\
\hline
\end{tabular}

Type 5 Pn. empyema

\begin{tabular}{c|c|c|c}
\hline \multirow{2}{*}{$\begin{array}{c}\text { Hyaluronidases } \\
\text { tested }\end{array}$} & \multicolumn{2}{|c|}{ Dates of sera } & $\begin{array}{c}\text { Multiple } \\
\text { change }\end{array}$ \\
\cline { 2 - 4 } & $\mathbf{3 / 2 1 / 4 7}$ & $\mathbf{4 / 4 / 4 7}$ & \\
\hline Pn. 1 & 384 & 1,536 & $\times 4$ \\
Pn. 2 & 192 & 768 & $\times 4$ \\
Pn. 7 & 192 & 1,536 & $\times 8$ \\
Testis & 3 & $\angle 3$ & $\times \angle 1$ \\
\hline
\end{tabular}

The immune serum antihyaluronidase reported here in patients with pneumococcus bacteremia has been reported previously to be thermostable; it is unaffected by heating at $56^{\circ} \mathrm{C}$. for one hour in a water bath (12). The hyaluronidase inhibitor of normal, non-immune serum has been reported to be thermolabile $(3,5,6)$. This study provides no evidence as to whether or not the hyaluronidase inhibitor of normal, non-immune serum specifically antagonizes a particular hyaluronidase.

\section{SUMMARY}

Series of sera from patients who suffered bacteremia due to pneumococcus, staphylococcus, B. typhosus, and B. Coli communis, were tested for 
antihyaluronidase against equivalent amounts of pneumococcus, staphylococcus, beta Hemolytic Streptococcus, $\mathrm{Cl}$. Welchii, and purified bovine testicular hyaluronidase. Patients with pneumococcus bacteremia exhibited rises in titer of serum antihyaluronidase antagonistic to pneumococcus hyaluronidase, but no rise in titer of antihyaluronidase antagonistic to the other hyaluronidases. One patient with Hemolytic Staphylococcus aureus bacteremia exhibited rise in titer of serum antihyaluronidase antagonistic to hyaluronidase elaborated by the same staphylococcus, but no rise in titer of antihyaluronidase antagonistic to pneumococcus and $\mathrm{Cl}$. Welchii hyaluronidases.

\section{CONCLUSION}

In human beings immunized by an infection which elaborates hyaluronidase the immune serum antihyaluronidase is specifically antagonistic to the hyaluronidase of the particular species of organism from which the antigen was derived, so far as the pneumococcus is concerned. This finding probably applies to the staphylococcus, and to other species of organisms which elaborate hyaluronidase.

\section{BIBLIOGRAPHY}

1. McClean, D., The in-vivo decapsulation of streptococci by hyaluronidase. J. Path. \& Bact., 1942, 54, 284.

2. Leonard, S. L., and Kurzrok, R., Inhibitors of hyaluronidase in blood sera and their effect on follicle cell dispersal. Endocrinology, 1946, 39, 85.

3. Haas, E., On the mechanism of invasion. I. Antinvasin $\mathrm{I}$, an enzyme in plasma. J. Biol. Chem., 1946, 163, 63.

4. Hechter, O., and Scully, E. L., Studies on spreading factors. II. The effect of serum upon hyaluronidase spreading activity. J. Exper. Med., 1947, 86, 19.

5. Hadidian, Z., and Pirie, N. W., The effects of serum and of hyaluronic acid derivatives on the action of hyaluronidase. Biochem. J., 1948, 42, 266.

6. Dorfman, A., Ott, M. L., and Whitney, R., The hyaluronidase inhibitor of human blood. J. Biol. Chem., 1948, 174, 621.
7. Duran-Reynals, F., The effect of antitesticular serum on the enhancement value of testicular extract. J. Exper. Med., 1932, 55, 703.

8. Hobby, G. L., Dawson, M. H., Meyer, K., and Chaffee, E., The relationship between spreading factor and hyaluronidase. J. Exper. Med., 1941, 73, 109.

9. McClean, D., and Hale, C. W., Studies on diffusing factors; the hyaluronidase activity of testicular extracts, bacterial culture filtrates and other agents that increase tissue permeability. Biochem. J., 1941, 35, 159.

10. McClean, D., A factor in culture filtrates of certain pathogenic bacteria which increases the permeability of the tissues. J. Path. \& Bact., 1936, 42, 477.

11. McClean, D., Studies on diffusing factors: II. Methods of assay of hyaluronidase and their correlation with skin diffusing activity. Biochem. J., 1943, 37, 169.

12. Thompson, R. T., Antihyaluronidase antagonistic to pneumococcus hyaluronidase in the serum of normal human beings and patients with pneumococcic pneumonia; rise of titer in bacteremic pneumococcic pneumonia. J. Lab. \& Clin. Med., 1948, 33, 919.

13. Thompson, R. T., and Blankenhorn, M. A., Antipneumococcus-hyaluronidase activity in human serum; rise in titer following pneumococcus bacteremia with purulent infection of pleura and synovia; preliminary report. Proc. Central Soc. Clin. Research, 1945, 18, 12.

14. Thompson, R. T., Antihyaluronidase activity in human serum which inactivates the hyaluronidases of types I, II and VII pneumococci: rise in titer following pneumococcus bacteremia. Proc. Central Soc. Clin. Research, 1947, 20, 16.

15. Thompson, R. T., and Moses, F. E., Specificity of human serum antihyaluronidase for antagonism of a particular species of bacterial hyaluronidase. Federation Proc., 1948, 7, 282.

16. Byers, S. O., Production and properties of bacterial hyaluronidase. University of Cincinnati Thesis, 1944.

17. Byers, S. O., Tytell, A. A., and Logan, M. A., The production of high titer clostridium perfringes hyaluronidase (spreading factor). J. Bact., 1944, 47, 456.

18. Friou, G. J., and Wenner, H. A., On the occurrence in human serum of an inhibitory substance to hyaluronidase produced by a strain of hemolytic streptococcus. J. Infect. Dis., 1947, 80, 185. 